DOI: https://doi.org/10.15407/techned2019.05.036

\title{
SUPPRESSION OF CURRENT HARMONICS FEEDING POWERFUL SINGLE-PHASE LOADS
}

Journal

Publisher

ISSN

Issue

Pages
Tekhnichna elektrodynamika

Institute of Electrodynamics National Academy of Science of Ukraine 1607-7970 (print), 2218-1903 (online)

No 5, 2019 (September/Oktober)

$36-42$

\section{Authors}

I.V. Volkov ${ }^{\star}$, V.P. Styazhkin ${ }^{\star \star}$, P.P. Podeiko ${ }^{\star \star \star}$

Institute of Electrodynamics National Academy of Sciences of Ukraine, pr. Peremohy, 56, Kyiv, 03057, Ukraine,

e-mail: tems@ukr.net

* ORCID ID : http://orcid.org/0000-0002-0696-0382

** ORCID ID : http://orcid.org/0000-0003-0602-1112

*** ORCID ID : http://orcid.org/0000-0001-9201-102X

\section{Abstract}

The hybrid filter of harmonics of the mains current of the power source of the electrothermal installation for the production of basalt super thin fiber (BSTF) in the heating mode of the draw plate is described. The filter uses a combined circuit of a passive broadband LMC filter cascaded with a transistor active filter. Mathematical modeling of such a filter and experimental verification of the effectiveness of harmonic suppression of the mains current are carried out. Experimental spectrograms and current diagrams were compared with similar simulation results, the models were confirmed to be adequate and can be used in the development of single-phase hybrid current-harmonic filters. References 8 , figures 9 , tables 3. 
Key words: current harmonic factor, THDi, LMC-filter, active filter of parallel type, hybrid filter, thyristor controller, transformer, distortion compensation.

Received: 01.02.2019

Accepted: 08.02.2019

Published: 01.08.2019

\section{References}

1. Muhammad H. Rashid. Power Electronics Handbook. N.-Y.: Academic Press, 2001, 876 p.

2. Styazhkin V.P., Podeiko P.P. Optimal control of the electro-technological unit for the production of basalt super-thin fiber. Visnyk Natsionalnoho Tekhnichnoho Universytetu KhPI. Tematychnyi vypusk: Problemy avtomatizirovannogo elektroprivoda. Teoriia i praktika. 2015. No 12 (1121). Pp. 124-127. (Rus)

3. Voldek A.I. Electrical machinery. Leningrad: Energiia, 1974. 839 p. (Rus)

4. IEC 61000-3-12:2011. Electromagnetic compatibility. Part 3-2: Limits. Limits for harmonic currents produced by equipment connected to public low-voltage systems with input current $>16 \mathrm{~A}$ and $\leq 75 \mathrm{~A}$ per phase.

5. Levin M., Volkov I. Universal Harmonic Mitigating System. Patent USA No 6127743, 2000.

6. Levin M., Volkov I. Harmonic mitigating device with magnetic shunt. Patent USA No 2006/0197385b A1, 2006.

7. Korn G. and Korn T. Handbook of mathematics for scientists and engineers. Moskva: Nauka, 1974. 832 p. (Rus)

8. Kolb A.A. Hybrid filters in power quality control devices. Elektromekhanichni $i$ enerhozberigayuchi systemy 2012. No 3(19). Pp. 250-253. (Rus) 